\title{
ANALISIS PINALTI HUKUM MATI KEPADA PERANTARA JUAL BELI NARKOTIKA DAN PEMBELIAN KATEGORI TANAMAN NARKOTIKA (STUDI KASUS NO. 1991/PID.SUS/2019/PN MDN)
}

\author{
Lesson Sihotang', Gelora Butar-butar ${ }^{2}$ \\ ${ }^{1,2}$ Program Studi Ilmu Hukum \\ Universitas HKBP Nommensen, Medan-Sumatera Utara-Indonesia \\ e-mail: sihotangmarsoit78@uhn.ac.id
}

\begin{abstract}
The problem of narcotics at this time has penetrated all elements of the nation, from children to adults, from the lower classes to officials, even law enforcers are not sterile from narcotics abuse. Its abuse is very dangerous to the future of the younger generation and threatens the existence of national security in a nation, so that it requires rules in the form of laws that regulate so as to reduce the number of abuse and distribution of narcotics. especially in Indonesia. The problem in this writing leads to the basis for the judge's consideration in imposing capital punishment on intermediary actors of narcotics sale and purchase group 1 (one) not plants in Decision Number: 1991 / Pid.Sus / 2019 / PN Mdn. Based on the results of the research and discussion carried out by the author in Decision Number: 1991 / Pid.Sus / 2019 / PN Mdn, the basis for the judge's consideration of imposing capital punishment on the intermediary narcotics buying and selling group I non-plant narcotics is based on judges' considerations juridically and non-juridically.considerations, Judicial namely valid evidence in the form of indictment, witness statements, evidence, documentary evidence, statement of the defendant revealed in court. The basis forconsiderations non-juridical consists of background actions, personal conditions, socio-economic conditions.
\end{abstract}

Keywords: Legal Analysis Basic Considerations of Judges, Death Penalty, Narcotics Buying and Selling Intermediaries Category I Not Plants

\begin{abstract}
Abstrak
Masalah narkotika saat ini telah merasuki semua elemen bangsa, mulai dari anak-anak hingga orang dewasa, dari kalangan bawah sampai pejabat, bahkan penegak hukum juga tidak steril dari penyalahgunaan narkotika. Sehingga dibutuhkan aturan berupa hukum yang mengatur sehingga dapat menekan jumlah penyalahgunaan dan peredaran narkotika khususnya di Indonesia. Permasalahan dalam penulisan ini mengarah pada dasar pertimbangan hakim dalam menjatuhkan pidana mati kepada pelaku perantara jual beli narkotika golongan 1 (satu) bukan tanaman dalam Putusan Nomor: 1991/Pid.Sus/2019/PN Mdn. Berdasarkan hasil penelitian dan pembahasan yang dilakukan oleh penulis dalam Putusan Nomor : 1991/Pid.Sus/2019/PN Mdn bahwa dasar pertimbangan hakim menjatuhkan pidana mati kepada pelaku perantara jual beli narkotika golongan I bukan tanaman berdasarkan pertimbangan Hakim secara yuridis dan Non yuridis. Pertimbangan secara Yuridis yaitu alat bukti yang sah berupa Dakwaan, Keterangan saksi, Barang bukti, Alat bukti surat, Keterangan terdakwa yang terungkap dipersidangan. Dasar pertimbangan non yuridis terdiri dari Latar belakang perbuatan, kondisi diri, kondisi sosial ekonomi.

Kata kunci: Analisis Hukum Dasar Pertimbangan Hakim, Pidana Mati, Perantara Jual Beli Narkotika Golongan I Bukan Tanaman
\end{abstract}




\section{A. Pendahuluan}

Perkataan narkotika berasal dari bahasa Yunani "narcosis" yang berarti "narkose" atau menidurkan, yaitu suatu zat atau obat-obatan yang membiuskan sehingga tidak merasakan apa-apa. Perkembangannya terjadi perubahan, dimana tidak hanya terbatas pada pengertian obat yang menyebabkan seseorang dapat tertidur, berubah menjadi bahan atau zat yang menyebabkan seseorang yang mempergunakannya menjadi tidur, yang disebut obat perangsang susunan saraf pusat. Berdasarkan Pasal 1 ayat (1) Undang-Undang Nomor 35 Tahun 2009 tentang Narkotika, disebutkan pengertian narkotika, yaitu zat atau obat yang berasal dari tanaman, baik sintesis maupun semisintesis, yang dapat menyebabkan penurunan atau perubahan kedasaran, hilangnya rasa, mengurangi sampai menghilangkan rasa nyeri, dan dapat menimbulkan ketergantungan, yang dibedakan kedalam golongan-golongan sebagaimana terlampir dalam Undang-undang. Narkotika ibarat pedang bermata dua, disatu sisi sangat dibutuhkan dalam dunia medis dan ilmu pengetahuan, dan dipihak lain penyalahgunaannya sangat membahayakan masa depan generasi mudah, ketentraman masyarakat dan mengancam eksistensi ketahanan nasional suatu bangsa, sehingga dapat dibutuhkan aturan berupa hukum yang mengatur sehingga dapat menekan jumlah penyalahgunaan dan peredaran narkotika, khususnya di Indonesia. Masalah narkotika saat ini telah merasuki semua elemen bangsa, mulai dari anak-anak hingga orang dewasa, dari kalangan bawah sampai pejabat, bahkan kalangan politisi dan penegak hukum juga tidak steril dari penyalahgunaan narkotika, sehingga upaya pemberantasannya tidak cukup hanya ditangani oleh pemerintah dan aparat penegak hukum saja melainkan perlu melibatkan seluruh masyarakat untuk berperan dan berpartisipasi aktif dalam pencegahan dan pemberantasan narkotika. Indonesia termasuk sebagai salah satu negara yang ditengarai sebagai tempat lintas narkotika, sehingga kejahatan narkotika bukan lagi kejahatan yang sifatnya lokal akan tetapi telah merebak sampai ke seluruh wilayah Indonesia dan sering dijadikan sebagai daerah transit oleh para pelaku sebelum sampai ke tempat tujuan (Negara lain). Oleh sebab itu angka perkembangan kasus narkotika dari tahun ke tahun semakin meningkat ${ }^{1}$ ). Penegakan hukum terhadap tindak pidana narkotika, telah banyak dilakukan oleh aparat penegak hukum dan telah banyak mendapat putusan hakim. Dengan demikian, penegakan hukum ini diharapkan mampu menjadi faktor penangkal terhadap merebaknya perdagangan gelap serta peredaran narkotika.

Dalam kenyataannya justru semakin intensif dilakukan penegakan hukum, semakin meningkat pula peredaran serta perdagangan gelap narkotika tersebut. Ketentuan perundangundangan yang mengatur masalah narkotika telah disusun dan diberlakukan, namun demikian kejahatan yang menyangkut narkotika ini belum dapat diredakan penyalahgunaan dan peredaran narkotika. Penyalahgunaan dan peredaran gelap narkotika di Indonesia sangat memprihatinkan. Narkotika juga sudah menyebar sampai ke pelosok pedesaan dan telah mengorbankan ribuan bahkan jutaan jiwa anak bangsa akibat terjerat narkotika. Berdasarkan data yang ada di BNN, hampir tidak ada daerah di Indonesia yang masyarakatnya tidak terpapar narkotika. Mencermati perkembangan penyalahgunaan dan peredaran gelap narkotika akhir-akhir ini telah mencapai situasi yang mengkhawatirkan, sehingga menjadi persoalan kenegaraan yang mendesak. Merujuk data BNN pada 2018, prevalensi angka penyalahgunaan narkoba di kalangan pelajar di 13 ibu kota provinsi di Indonesia mencapai 
angkta 3,2 persen atau setara dengan 2,29 juta orang. Sementara, pada 2017, BNN mencatat angka prevalensi penyalahgunaan narkotika sebesar 1,77 persen atau setara 3.376.115 orang pada rentang usia 10-59 tahun Penyalahgunaan narkotika tentu dikarenakan peredaran gelap secara bebas yang dilakukan oleh pengedar dan terutama Bandar narkotika. Pelaku peredaran gelap narkotika adalah invidu yang melakukan aktivitas peredaran narkotika illegal. Pelaku peredaran gelap narkotika biasanya dilakukan dalam kelompok terorganisir/terstruktur melalui jaringan terputus. Oleh karena itu, dalam usaha untuk menanggulangi masalah penyalahgunaan dan peredaran gelap narkotika pemerintah telah mengeluarkan UndangUndang Republik Indonesia Nomor 35 Tahun 2009 tentang Narkotika. Pengelompokan kejahatan pada undang-undang Narkotika dan Psikotropika pada dasarnya tidak berbeda, yaitu. Di dalam Bab VI Undang-Undang Nomor 35 tahun 2009, dari Pasal 35 sampai dengan Pasal 47 menjelaskan mengenai peredaran narkotik. Peredaran narkotika yang dimaksud adalah peredaran narkotika meliputi setiap kegiatan atau serangkaian kegiatan penyaluran atau penyerahan Narkotika, baik dalam rangka perdagangan, bukan perdagangan maupun pemindahtanganan, untuk kepentingan pelayanan kesehatan dan pengembangan ilmu pengetahuan dan teknologi. Pelanggaran terhadap peraturan itu diancam dengan pidana yang tinggi dan berat dengan dimungkinkannya terdakwa divonis maksimal yakni pidana mati selain pidana penjara dan pidana denda. Isi putusan Mahkamah Konstitusi RI Nomor 23/PUU-V/2007 dijelaskan bahwa penerapan sanksi pidana mati bagi para pelaku tindak pidana narkotika tidak melanggar hak asasi manusia, karena terdapat asas (derogble right) yaitu hak seseorang yang bisa dibatasi, akan tetapi justru para pelaku tersebut telah melanggar hak asasi manusia lain yang memberikan dampak terhadap kehancuran generasi muda yang akan datang. Dan ditinjau melalui pendekatan filosofis kemanusiaan bahwa hukuman dengan pidana mati sangat pantas dijatuhkan kepada para penyalahgunaan narkotika tersebut, terutama terhadap ringan dan para pengedarnya. Oleh karena akibat dari perbuatan tersebut sangat berat bobot kejahatannya, yang pada akhirnya dapat menghancurkan hampir kebanyakan generasi muda dari sebuah bangsa. Dan pada akhirnya, seperti lazimnya berat ringan penjatuhan pidana sangat tergantung kepada proses sidang peradilan dan kenyakinan serta penilaian hakim yang melakukan pemeriksaan suatu perkara pidana khususnya dalam tindak kejahatan narkotika.

\section{B. Metode Penelitian}

Jenis penelitian hukum ini termasuk penelitian yuridis normatif yaitu penelitian yang berdasarkan pada bahan kepustakaan yang ada. Penelitian ini dengan pendekatan studi kasus yang meliputi ketentuan perundang-undangan dan putusan pengadilan serta literatur-literatur yang berhubungan dengan pokok bahasan.

\section{Pembahasan}

Berdasarkan hasil penelitian yang telah dilakukan terhadap putusan Pengadilan Negeri Medan dengan nomor: 1991/Pid.Sus/2019/PN Mdn,dapat diperoleh data sebagi berikut:

$\begin{array}{ll}\text { Identitas Terdakwa } & \\ \text { Nama Lengkap } & \text { : Hasanuddin Alias Hasan Alias } \\ & \text { Cek Gu Bin Suharyanto } \\ \text { Tempat Lahir } & : \text { Tanjung Balai } \\ \text { Umur/Tanggal lahir } & \text { : } 30 \text { tahun/o2 Oktober } 1989 \\ \text { Jenis Kelamin } & \text { Laki-laki } \\ \text { Kebangsaan } & \text { Indonesia } \\ \text { Tempat Tinggal } & \text { : Jalan M.T. Haryono LK.III, Kelurahan Selat Tanjung Medan, }\end{array}$


Kecamatan Datuk Bandar Timur, Kota Tanjung Balai, Provinsi Sumatera Utara/Sei SilauTimur Simpang Murni, Dusun 1A, Kecamatan Buntu Pane, Kabupaten Asahan, Kisaran, Provinsi Sumatera Utara,

Agama : Islam

Pekerjaan

: Wiraswasta/Nelayan

Pendidikan

:SD

Bahwa pada waktu yang tidak dapat diingat secara pasti dalam bulan September 2018, terdakwa yang telah diberitahu oleh seseorang yang dikenal dengan sebutan TONI alias MIKE (Dalam daftar Pencarian Orang) untuk mengatur penjualan shabu-shabu di sekitar Medan Meskipun terdakwa mengetahui bahwa shabu-shabu termasuk jenis narkotika yang dilarang peredarannya di wilayah Republik Indonesia apabila tidak mempunyai ijin dari pihak berwenang dan terdakwa mengetahui dirinya tidak mempunyai kewenangan untuk turut serta dalam hal pengadaan, penyimpanan dan pendistribusian narkotika tetapi terdakwa menyanggupi permintaan tersebut dengan maksud untuk mendapatkan keuntungan sebagai perantara dan setelah terdakwa menerima bantuan dari Sdr. Toni alias Mike bahwa shabushabu siap didistribusikan maka terdakwa meminta kepada Suhardi Nasution Alias Hardi Alias Adi Bin Abu Kosim (penuntutan) diajukan secara terpisah) untuk menerima penyerahan shabu-shabu sebanyak 4o (empat puluh) kilogram dari Toni alias Mike melalui kurirnya. Bahwa terdakwa juga menerima pemberitahuan dari Sdr. Toni alias Mike tentang kepada siapa saja shabu-shabu tersebut untuk didistribusikan selanjutnya terdakwa dengan mempergunakan telpon dengan nomor o8236196675 milik terdakwa telah meneruskan isi pesan pendistribusiannya kepada Alfirmansyah (dalam daftar Pencarian Orang) dan oleh karena Al Firmasyah tidak memiliki telpon dengan aplikasi pesan wahtsapp maka Al Firmasyah bekerjasama untuk pendistribusiannya bersama dengan M. Razief alias Ajib bin H.M. Bachid (berkas terpisah dan perkaranya telah disidangkan di PN Medan) yang memiliki telon genggam dengan no. 087777012726 , dengan isi pesan yang berasal dari telpon terdakwa adalah berupa daftar distribusi penerima sebagai berikut :

1) 082362576053 code 101 bagi 5 , adalah penerimadengan yang memiliki/menguasai telpon genggang dengan simcard nomor o823 62576053 mendapat penyerahan 5 (lima) paket ( 1 paket $=1 \mathrm{~kg}$ ) shabu.

2) Griya Hotel, code 102 bagi 5, adalah penerimadengan yang berada di Hotel Griya mendapat penyerahan 5 (lima) paket (1 paket $=1 \mathrm{~kg}$ ) shabu

3) 081375127447 code 103 bagi 1, adalah penerimadengan yang memiliki/menguasai telpon genggang dengan simcard nomor o813 75127447 mendapat penyerahan 1 (satu) paket (1 paket $=1 \mathrm{~kg}$ ) shabu.

4) o813 61925087 code 77 bagi 9, adalah penerimadengan yang memiliki/menguasai telpon genggang dengan simcard nomor o813 61925087 mendapat penyerahan 9 (sembilan) paket ( 1 paket $=1 \mathrm{~kg}$ ) shabu.

5) o877 66489147 code 104 bagi 14, adalah penerimadengan yang memiliki/menguasai telpon genggang dengan simcard nomor o877 66489147 mendapat penyerahan 14 (empat belas) paket (1 paket $=1 \mathrm{~kg}$ ) shabu

\section{Dakwaan}

Adapun yang menjadi dakwaan yang diajukan oleh Jaksa Penuntut Umum di persidangan adalah sebagai berikut: 
1) Perbuatan Terdakwa Hasanuddin Alias Cekgu Bin Suharyanto, diancam pidana sebagaimana diatur dalam pasal 114 ayat (2) Jo Pasal 132ayat (1) UU No. 35 Tahun 2009 tentang Narkotika.

2) Perbuatan Terdakwa Hasanuddin Alias Cekgu Bin Suharyanto, diancam pidana sebagaimana diatur dalam Pasal 112 ayat (2) Jo. Pasal 132 ayat (1) UU No. 35 Tahun 2009 tentang Narkotika.

3) Perbuatan Terdakwa Hasanuddin Alias Hasan Alias Cekgu Bin Suharyanto diatur dan diancam pidana dalam Pasal 112 ayat (1) Jo Pasal 132 ayat (1) UU No.35 Tahun 2009 tentang Narkotika.

\section{Tuntutan}

Surat Tuntutan Umum yang pada pokoknya sebagai berikut:

Menyatakan Terdakwa Hasanuddin Als Hasan Als Cekgu Bin Suharyanto telah terbukti secara sah dan meyakinkan bersalah melakukan tindak pidana percobaan dan permufakatan jahat untuk melakukan tindak pidana narkotika dan prekursor narkotika tanpa hak atau melawan hukum menawarkan untuk dijual, menjual, membeli, menerima, menjadi perantara dalam jual beli, menukar, atau menyerahkan Narkotika Golongan I bukan tanaman beratnya melebihi 5(lima) gram, sebagaimana diatur dan diancam pidana dalam Pasal 114 Ayat (2) Jo Pasal 132 Ayat (1) Undang-Undang Republik indonesia No.35 Tahun 2009 Tentang Narkotika dalam surat dakwaan Kesatu Primair. Dan Terdakwa Hasanuddin Als Hasan Als Cekgu Bin Suharyanto telah terbukti secara sah dan meyakinkan bersalah melakukan Tindak Pidana percobaan atau permuufakatan jahat untuk melakukan tindak pidana narkotika dan Prekursor Narkotika tanpa hak atau melawan hukum memiliki, menyimpan, menguasai, atau menyediakan Narkotika Golongan I bukan tanaman, sebagaimana diatut dan diancam pidana dalam Pasal 112 Ayat (1) Jo Pasal 132 Ayat (1) Undang-Undang Republik Indonesia No.35 Tahun 2009 Tentang Narkotika dalam surat dakwaan kedua;

1) Menjatuhkan pidana terhadap terdakwa Hasanuddin Als Hasan Als Cekgu Bin Suharyanto berupa Pidana Mati;

2) Menyatakan barang bukti berupa $1(\mathrm{satu})$ unit handphone Nokia dengan nomor telepon 082273560076 dirampas untuk dimusnahkan dan 1(satu) lembar KTP Hasanuddin dikembalikan kepada terdakwa Hasanuddin Als. Hasan Als Cekgu Bin Suharyanto;

3) Menetapkan biaya perkara dalam perkara terdakwa Hasanuddin Als Hasan Als Cekgu Bin Suharyanto dibebankan kepada Negara sebesar Rp. 5000.- (lima ribu rupiah);

a. Keterangan Terdakwa

- Bahwa Terdakwa membenarkan keterangannya dalam Berita Acara Pemeriksaan Tersangka di depan Penyidik Badan Narkotika Nasional tertanggal 6 Maret 2019, tanggal 26 Maret 2019 dan tanggal 2 Mei 2019;

- Bahwa Terdakwa ditangkap oleh Petugas BNN sebanyak 2 (dua) kali, yang pertama adalah pada hari Senin tanggal 17 September 2018 sekira jam 20.0o Wib di Kamar 412 Hotel Grand Sakura yang beralamat di Jl.Prof HM. Yamin SH No.41 Perintis Kec.Medan Timur Kota Medan - Sumatera Utara namun Terdakwa berhasil melarikan diri;

b. Surat

Bahwa di dalam berkas perkara telah dilampirkan berita Acara Pemeriksaan Laboratorium Forensik terhadap barang bukti Narkotika baik yang disita dari dalam pengananganan perkara dalam berkas perkara dengan Penuntutan Terpisah yang saling berhubungan dan merupakan bagian yang tidak terpisahkan dengan berkas perkara terdakwa Hasanuddin Alias Hasan Alias Cekgu Bin Suharyanto yaitu yang terdapat 
didalam berkas perkara atas nama: Dalam berkas perkara penuntutan terpisah Suhardi Nasution Als Hardi Als.Adi Bin Alm. Abu Kosim. Berdasarkan Berita Acara Pemeriksaan Laboratorium No. 442 AU/IX/2018/BALAI LAB NARKOBA tanggal 26 September 2018 Balai Laboratorium BNN RI atas nama Hardi Nasution Als Hardi (DPO) dalam kesimpulannya menyatakan barang bukti:

1. 1 (satu) bungkus plastic bening kode $\mathrm{C}_{2}$ berisikan 3 (tiga) butir tablet warna orange logo "Trump" dengan berat netto seluruhnya 1,3449 gram

2. 1 (satu) bungkus plastic bening kode $A_{7}$ berisikan kristal warna putih dengan berat netto o,7392 gram,

3. 1 (satu) bungkus plastic bening kode Aıo berisikan kristal warna putih dengan berat netto o,6968 gram,

4. 1 (satu) bungkus plastic bening kode Aı berisikan kristal warna putih dengan berat netto o,6552 gram,

5. 1 (satu) bungkus plastic bening kode $\mathrm{B}_{7}$ berisikan kristal warna putih dengan berat netto o,6634 gram,

6. 1 (satu) bungkus plastic bening kode B8 berisikan kristal warna putih dengan berat netto o,670o gram,

7. 1 (satu) bungkus plastic bening kode Bı1 berisikan kristal warna putih dengan berat netto o,6223 gram,

Dengan kesimpilan sebagai berikut:

- Barang bukti no. urut 1 dengan kode $C_{2}$ berupa ablet warna orange $\neg$ logo "Trump" dengan berat netto seluruhnya 1,3449 gram adalah benar mengandung MDMA +)$\mathrm{N}$, alfa-dimetil-1,4 (Metilendioksi) fenetilamina terdaftar dalam Golongan I nomor urut 37 Lampiran Undang-undang Republik Indonesia No. 35 Tahun 2009 tentang Narkotika

- $\quad$ Barang bukti no. urut 2 s.d. no. 7 dengan kode A7, A1o, A11, B7, B8, $\neg$ BII adalah Benar mengandung Metamfetamina dan terdaftar terdaftar dalam Golongan I Nomor Urut 61 Lampiran Undang-undang Republik Indonesia No.35 Tahun 2009 tentang Narkotika;

2. Barang Bukti

Disita dari terdakwa Hasanuddin Alias Hasan Alias Cekgu Bin Suharyanto:

- 1 (satu) unit handphone Nokia dengan nomor telepon 6282273560o76;

- Fotocopy KTP atas nama Hasanuddin;

Menimbang, bahwa untuk menjatuhkan pidana terhadap Terdakwa, maka perlu dipertimbangkan terlebih dahulu keadaan yang memberatkan dan yang meringankan Terdakwa:

a. Hal yang memberatkan

* Perbuatan Terdakwa tidak mendukung program pemerintah, khususnya Kepolisian Negara Republik Indonesia yang sedang giat-giatnya memberantas peredaran narkotika dan obat-obat terlarang;

- Perbuatan Terdakwa selain merugikan diri sendiri juga merugikan masyarakat, khususnya kaum muda, yang pada akhirnya merusak masa depan bangsa;

b. Hal yang meringankan tidak ditemukan pada diri Terdakwa

Putusan pengadilan Negeri Medan Nomor 1991/Pid.Sus/2019/PN Mdn, tanggal 4 Desember 2019, yang berbunyi sebagai berikut:

1. Menyatakan terdakwa Hasanuddin Alias Hasan Alias Cekgu Bin Suharyanto tersebut diatas, terbukti secara sah dan meyakinkan bersalah melakukan tindak pidana "Dengan permufakatan jahat tanpa hak atau melawan hukum menjadi perantara dalam jual beli, 
menyerahkan Narkotika Golongan I bukan tanaman yang beratnya lebih dari 5 (lima) gram" dan "Dengan permufakatan jahat tanpa hak atau melawan hukum menguasai atau memiliki Narkotika Golongan I bukan tanaman ";

2. Menjatuhkan pidana terhadap Terdakwa dengan pidana mati;

3. Memerintahkan Terdakwa tetap berada dalam tahan;

4. Menetapkan barang bukti berupa:

* 1 (satu) unit Handphone Nokia dengan nomor 082273560o76; Dirampas untuk dimusnahkan;

* 1 (satu) lembar Kartu Tanda Penduduk (KTP) Hasanuddin; Dikembalikan kepada

Terdakwa Hasanuddin Alias Hasan Alias Cekgu Bin Suharyanto;

5. Membebankan kepada biaya perkara kepada Negara;

Analisis Dakwaan adalah tuntutan perkara yang diberikan oleh jaksa penuntut umum dalam bentuk surat dakwaan. Pasal 143 KUHAP menyatakan secara jelas bahwa untuk mengadili suatu perkara, Penuntut Umum wajib mengajukan permintaan disertai dengan suatu surat dakwaan. Jaksa Agung mengeluarkan Surat Edaran Jaksa Agung Nomor SE-o04/J.A/11/1993 tentang Pembuatan Surat Dakwaan. Surat Edaran tersebut ditujukan agar dapat keseragaman para Penuntut Umum dalam membuat surat dakwaan. Dalam Surat Edaran ini, disebutkan tentang bentuk-bentuk surat dakwaan antara lain :

1) Dakwaan Tunggal

Dalam surat dakwaan ini hanya satu Tindak Pidana saja yang didakwakan, karena tidak terdapat kemungkinan untuk mengajukan alternatif atau dakwaan pengganti lainnya;

2) Dakwaan Alternatif

Dalam surat dakwaan ini terdapat beberapa dakwaan yang disusun secara berlapis, lapisan yang satu merupakan alternatif dan bersifat mengecualikan dakwaan pada lapisan lainnya. Bentuk dakwaan ini digunakan bila belum didapat kepastian tentang Tindak Pidana mana yang paling tepat dapat dibuktikan. Dalam dakwaan alternatif, meskipun dakwaan terdiri dari beberapa lapisan, hanya satu dakwaan saja yang dibuktikan tanpa harus memperhatikan urutannya dan jika salah satu telah terbukti maka dakwaan pada lapisan lainnya tidak perlu dibuktikan lagi. Dalam bentuk Surat Dakwaan ini, antara lapisan satu dengan yang lainnya menggunakan kata sambung atau.

3. Dakwaan Subsidair

Sama halnya dengan dakwaan alternatif, dakwaan subsidair juga terdiri dari beberapa lapisan dakwaan yang disusun secara berlapis dengan maksud lapisan yang satu berfungsi sebagai pengganti lapisan sebelumnya. Sistematik lapisan disusun secara berurut dimulai dari Tindak Pidana yang diancam dengan pidana tertinggi sampai dengan Tindak Pidana yang diancam dengan pidana terendah.

4. Dakwaan Kumulatif

Dalam Surat Dakwaan ini, didakwakan beberapa Tindak Pidana sekaligus, ke semua dakwaan harus dibuktikan satu demi satu.Dakwaan yang tidak terbukti harus dinyatakan secara tegas dan dituntut pembebasan dari dakwaan tersebut.Dakwaan ini dipergunakan dalam hal Terdakwa melakukan beberapa Tindak Pidana yang masingmasing merupakan Tindak Pidana yang berdiri sendiri.

5. Dakwaan Kombinasi

Dakwaan kombinasi adalah surat dakwaan yang merupakan kombinasi dari dakwaan yang berbentuk alternatif dengan dakwaan subsidair/antara dakwaan kumulatif dengan dakwaan subsidair/antara dakwaan kumulatif dengan dakwaan alternatif, dan 
sebagainya. Dakwaan ini harus diperhatikan secara teliti mengenai bentuk-bentuk dari kumulasinya, dan jangan sampai upaya untuk mencegah terdakwa lepas dari dakwaan justru memperluas kemungkinan terdakwa untuk lepas dari dakwaan. Timbulnya bentuk ini sering dengan perkembangan di bidang kriminalitas yang semakin variatif baik dalam bentuk/jenisnya maupun modus operandi yang dipergunakan.

Berdasarkan surat dakwaan yang diberikan penuntut umum, dengan dakwaan kumulatif subsidairitas yang didakwakan terhadap terdakwa, dalam kronologis yang disebutkan pada Putusan Nomor 1991/Pid.Sus/2019/PN Mdn. Sangat jelas disebutkan bahwa terdakwa merupakan suruhan dari seseorang yang dikenal dengan sebutan Toni alias Mike (DPO) untuk melakukan penjemputan narkotika dan serahterima serta penyerahan narkotika tersebut dan terdakwa juga melakukan tindak pidana nakotika lainnya yaitu menyuruh seseorang bernama M. Razief alias Roni alias Ajib Bin H. Muhammad Bachiedd untuk menyarikan \pm 2 gram untuk digunakan bersama sama dan sebelumnya juga terdakwa telah memiliki narkotika jenis shabu yang beratnya \pm 2 gram. Penulis sepakat dengan dakwaan yang diberikan oleh penuntut umum karena dakwaan yang diberikan terdiri dari dakwaan kumulatif subsidaritas yaitu dakwaan yang berisikan tentang perbuatan pidana yang dilakukan oleh terdakwa sebagai perantara jual beli , menyerahkan dan menerima narkotika golongan I bukan tanaman sesuai dengan dakwaan kesatu primair Pasal 114ayat (2) Jo Pasal 132 ayat (1) UU No. 35 Tahun 2009, Subsidair Pasal 112 ayat (2) Jo Pasal 132 ayat (1) UU No. 35 Tahun 2009 Tentang Narkotika dan sebagai orang yang melawan hukum memiliki, menyimpan, menguasai narkotika golongn I bukan tanaman sesuai dengan dakwaan kedua Pasal 112 ayat (1) Jo Pasal 132 ayat (1) UU No. 35 Tahun 2009 tentang Narkotika. Penuntut umum menggunakan ini karena tindak pidana yang satu dengan yang lainnya saling berdiri sendiri dan tidak ada hubungan dengan tindak pidana yang lain dan didakwakan secara serempak karena pelaku tindak pidana itu adalah sama. Dakwaan ini harus diperhatikan secara teliti mengenai bentuk-bentuk kumulasinya, dan jangan sampai upaya untuk mencegah terdakwa lepas dari dakwaan justru memperluas kemungkinan terdakwa untuk lepas dari dakwaan. Timbulnya bentuk ini seiring dengan perkembangan di bidang kriminalitas yang semakin variatif baik dalam bentuk/jenisnya maupun dalam modus operandi yang dipergunakan.

b) Analisis Tuntutan

Penuntut umum menuntut terdakwa Hasanuddin alias Hasan alias Cek gu Bin Suharyanto dengan Pasal 114 Ayat (2) Jo Pasal 132 Ayat (1) Undang-Undang No. 35 Tahun 2009 Tentang Narkotika dan Pasal 112 Ayat (1) Jo Pasal 132 Ayat (1) Undang-Undang No. 35 Tahun 2009 Tentang Narkotika. Dalam tuntutan yang diajukan oleh Jaksa Penuntut Umum, terdakwa dituntut pidana mati. Berdasarkan perbuatan terdakwa mengakibatkan dampak yang besar terhadap program pemerintah khususnya Kepolisian Negara Republik Indonesia yang sedang giat-giatnya memberantas peredaran narkotika dan obat-obat terlarang. Penulis setuju dengan pasal-pasal yang dituntut oleh Jaksa Penuntut Umum, tetapi penulis tidak sependapat dengan pidana yang dijatuhkan oleh Jaksa Penuntut Umum kepada terdakwa yakni pidana mati. Hukuman tersebut terlalu berat dimana terdakwa hanya menjadi perantara jual beli, menyerahkan, atau menerima Narkotika golongan 1 dan ia juga tidak terlibat langsung melainkan menyuruh orang lain untuk melakukannya dan dakwaan kedua terdakwa hanya memiliki sabu \pm 4 gram, jadi menurut penulis tuntutan pidana mati yang di jatuhkan Jaksa Penuntut Umum terlalu berat dan tidak adanya kesempatan yang diberikan kepada terdakwa untuk menyesali dan merubah dirinya.

c) Analisis Dasar Pertimbangan Hakim 
Adapun yang menjadi dasar pertimbangan hakim dalam menjatuhkan hukuman kepada terdakwa didasarkan pada fakta-fakta hukum yang ditemukan dalam proses penyidikan sampai dengan proses persidangan yang di dalamnya terdapat dasar pertimbangan hakim bersifat yuridis dan dan non yuridis. Yang menjadi dasar pertimbangan hakim dalam menjatuhkan putusan berifat yuridis yaitu :

a. Dakwaan Penuntut Umum

Adanya dakwaan penuntut umum yang merupakan dasar dari jalannya suatu pemeriksaan dalam proses persidangan untuk mengetahui tindak pidana yang dilakukan, yaitu dalam analisis penulis maka tindak pidana yang terjadi adalah tindak pidana narkotika dimana terdakwa menjadi perantara dalam jual beli narkotika menerima, atau menyerahkan dan memiliki, menyimpan dan menguasai narkotika golongan I bukan tanaman.

b. Keterangan Terdakwa oleh Hasanuddin alias Hasan alias Cek Gu Bin Suharyanto Terdakwa mengakui dan menyatakan bahwa terdakwa telah melakuka suatu tindak pidana sesuai dengan dakwaan penuntut umum yang merupakan tindak pidana Narkotika dimana terdakwa menjadi perantara dalam jual beli narkotika menerima, atau menyerahkan dan memiliki, menyimpan dan menguasai narkotika golongan I bukan tanaman.

c. Keterangan Saksi

Dalam hal keterangan saksi, dalam Putusan Nomor 1991/Pid.Sus/2019/PN Mdn, saksi didatangkan oleh penuntut umum yaitu Saksi Marudut R.L.,S.H.,M.H, David Ricardo Hutasoit, Dahri Effenddi yang ketiganya merupakan anggota Kepolisian yang melakukan penangkapan terhadap terdakwa dan juga Jaksa penuntut umum mendatangkan saksi yang berhubungan dengan tindak pidana tersebut yakni saksi M.Razief als Azib Bin Muhammad Bachid, saksi Husaini alias Gendut, saksi Jimmy alias Wong

d. Barang Bukti

Adapun yang menjadi barang bukti dalam persidangan yang diajukan oleh penuntut umum antara lain:

* 1 (satu) unit Handphone Nokia dengan nomor 082273560076;

* 1 (satu) lembar Kartu Tanda Penduduk (KTP) a.n. Hasanuddin

Sedangkan dasar pertimbangan hakim lainnya yang menjadi dasar pertimbangan majelis hakim dalam menjatuhkan hukuman yaitu dasar pertimbangan yang bersifat non yuridis berupa latar belakang terdakwa, keadaan jiwa terdakwa, dampak dari perbuatan terdakwa yang tidak mendukung program pemerintah, khususnya Kepolisian Negara Republik Indonesia yang sedang giat-giatnya memberantas peredaran narkotika dan obat-obat terlarang dan agama terdakwa. Selain pada itu, hakim juga mempertimbangkan unsur-unsur tindak pidana yang diduga di lakukan oleh terdakwa Hasanuddin alias Hasan alias Cek Gu Bin Suharynto, yaitu;

Unsur-unsur pada Pasal 114 ayat (2) Jo Pasal 132 ayat (1) Undang-Undang No. 35 Tahun 2009 dakwaan Kesatu Primer yaitu:

Ad. 1. Unsur Setiap Orang

Bahwa yang dmaksud dengan unsur setiap orang adalah pelaku/subjek hukum yang melakukan tindak pidana baik itu laki-laki atau perempuan yang merupakan pendukung hak dan kewajiban. Dalam unsur setiap orang ini adalah orang yang merupakan terdakwa Hasanuddin alia Hasan alias Cek Gu Bin Suharyanto dan merupakan subjek hukum yang dapat 
mempertanggungjawabkan perbuatannya. Dan oleh karena itu majelis hakim berpendapat bahwa unsur setiap orang telah terpenuhi.

Ad. 2. Unsur Tanpa Hak atau Melawan Hukum

Oleh karena tidak adanya saksi yang menerangkan bahwan terdakwa adalah seorang dokter, atau apoteker, petugas puskesmas, petugas balai kesehatan, ilmuan ataupun balai pengobatan yang diberikan wewenang untuk melakukan penyaluran atau penyerahan narkotika Gol. I, melainkan terdakwa adalah seorang nelayan. Terdakwa juga tidak ada menunjukkan surat keterangan dari pihak yang berwenang yang menerangkan terdakwa adalah orang yang diberi ijin atau kuasa untuk melakukan penyaluran dan penyerahan narkotika golongan I, maka majelis hakim menyatakan bahwa unsur ini telah terpenuhi dalam perbuatan terdakwa.

Ad. 3. Unsur dengan permufakatan jahat

Menawarkan untuk dijual, menjual, membeli, menerima menjadi perantara dalam jual beli, menukar atau menyerahkan Narkotika Golongan I bukan tanaman yang beratnya lebih dari 5 (lima) gram: Bahwa menurut Pasal 1 ke 18 U.U. No. 35 Tahun 2009 tentang Narkotika, yang dimaksud dengan permufakatan jahat adalah perbuatan dua orang atau lebih yang bersekongkol atau bersepakat untuk melakukan, melaksanakan, membantu, turut serta melakukan, menyuruh, mengajurkan, memfasilitasi, member konsultasi, menjadi anggota suatu organisasi kejahatan Narkotika atau mengorganisasikan suatu tindak pidana Narkotika. Bahwa terdakwa disuruh oleh seseorang yang bernama Mike alias Toni untuk melakukan penjemputan dan serah terima serta penyerahan narkotika tersebut di laut, terdakwa mengaku sudah 2 kali melakukan penjemputan, tetapi yang melakukan penjemputan bukanlah terdakwa langsung melainkan ia menyuruh orang lain yang bernama Suhardi, penjemputan pertama kalinya adalah sekitar bulan September 2018 sebanyak 40 paket yang per paketnya adalah $1 \mathrm{~kg}$, dan penjemputan yang kedua terjadi pada tanggal 17 September 2018 sekira jam 19.0o Wib atau pertengahan bulan September 2018 sebanyak 31 paket dimana 30 paket merupakan sabu-sabu dengan berat \pm 30.948 gram dan 1 paket merupakan ekstasi sebanyak 2.985 butir. Setelah penjemputan yang pertama kali terdakwa menyuruh Suhardi untuk menyerahkan narkotika tersebut kepada Razief dan Alfirmansyah dengan tujuan agar narkotika tersebut agar diserahkan kepada penerima yang dimana daftar penerima dan banyaknya paket telah dikirimkan oleh terdakwa yang sebelumnya di kirim oleh pemilik narkotika yaitu Mike alias Toni. Perbuatan tersebut melibatkan beberapa orang mulai dari pengiriman Narkotika, penjemputan Narkotika sebanyak dua kali ke tengah Laut hingga pendistribusian Narkotika , maka Terdakwa dan kawan-kawan telah melakukan permufakatan jahat. maka majelis hakim menyatakan bahwa unsur ini telah terpenuhi dalam perbuatan terdakwa.

Unsur-unsur pada Pasal 114 ayat (2) Jo Pasal 132 ayat (1) Undang Undang No. 35 Tahun 2009 dakwaan Kedua yaitu:

1. Ad. 1. Unsur Setiap Orang Bahwa yang dimaksud dengan unsur setiap orang adalah pelaku/subjek hukum yang melakukan tindak pidana baik itu laki-laki atau perempuan yang merupakan pendukung hak dan kewajiban. Dalam unsur setiap orang ini adalah orang yang merupakan terdakwa Hasanuddin alia Hasan alias Cek Gu Bin Suharyanto dan merupakan subjek hukum yang dapat mempertanggungjawabkan perbuatannya, oleh karena itu majelis hakim berpendapat bahwa unsur setiap orang telah terpenuhi.

2. Ad. 2. Unsur dengan permufakatan jahat tanpa hak dan melawan hukum memiliki, menyimpan, menguasai, atau menyediakan Narkotika Golongan I bukan tanaman. Bahwa menurut Pasal 1 ke 18 U.U. No. 35 Tahun 2009 tentang 
Narkotika, yang dimaksud dengan permufakatan jahat adalah perbuatan dua orang atau lebih yang bersekongkol atau bersepakat untuk melakukan, melaksanakan, membantu, turut serta melakukan, menyuruh, mengajurkan, memfasilitasi, member konsultasi, menjadi anggota suatu organisasi kejahatan Narkotika atau mengorganisasikan suatu tindak pidana Narkotika. Bahwa terdakwa telah memiliki sabu-sabu dengan tanpa hak tanpa dan tidak mempunyai ijin dari pihak berwenang untuk memili, menyimpan, menguasai, atau menyediakan narkotika golongan I. Pada mulanya senin 17 september 2018 terdakwa Hasanuddin menghubungi M.Razief dengan maksud untuk mencarikan sabu-sabu yang selanjutnya di bawa ke hotel Sakura untuk digunakan bersama-sama, sebelumya terdakwa telah memiliki 1 paket sabusabu yang beratnya \pm 2 gram, akhirnya M.Razief berhasil mendapatkan sabusabu dan langsung menghubungi terdakwa, sesampainya di hotel sakura dan bertemu terdakwa mengajak M. Razief untuk langsung masuk menuju kamar 462 hotel sakura yang telah di persiapkan oleh terdakwa Hasanuddin dan selanjutnya terdakwa menyiapkan alat hisap sabu-sabu yakni berupa bong. Selanjutnya beberapa petugas dari BNN datang untuk menangkap terdakwa bersama M.Razief tetapi terdakwa berhasil melarikan diri dan dalam penangkapan tersebut ditemukan 2 (bungkus) sabu-sabu yakni 1 paket milik terdakwa beratnya \pm 2 gramdan satu paket lainnya milik terdakwa yang dibeli M.Razief dari seseorang dengan harga Rp. 1.500.00o,oo beratnya \pm 2 gram. Terdakwa telah melakukan permufakatan jahat tanpa hak memiliki, menyimpan dan menguasai narkotika golongan I bukan tanaman dengan M.Razief, berdasarkan hal-hal yang dipertimbangkan diatas maka hakim menyatakan bahwa unsur ini telah terpenuhi dalam perbuatan terdakwa.

\section{d) Analisis Putusan Hakim}

Setelah menganalisis kasus Putusan Nomor 1991/Pid.Sus/2019/PN Mdn, maka penulis mengambil kesimpulan mengenai pemidanaan terhadap pelaku tindak pidana adalah bahwa terdakwa Hasanuddin alias Hasan alias Cek Gu Bin Suharyanto telah terbukti secara sah dan meyakinkan bersalah melakukan tindak pidana "Dengan permufakatan jahat tanpa hak atau melawan hukum menjadi perantara dalam jual beli, menyerahkan Narkotika Golongan I bukan tanaman yang beratnya lebih dari 5 (lima) gram" dan "Dengan permufakatan jahat tanpa hak atau melawan hukum menguasai atau memiliki Narkotika Golongan I bukan tanaman”. Hal ini terbukti bahwa dalam persidangan Jaksa Penuntut Umum mengajukan dakwaan kumulatif subsidaritas yaitu dakwaan kesatu primer Pasal 114 ayat (2) Jo 132 ayat (1) UU No. 35 Tahun 2009 tentang Narkotika, yang unsur-unsurnya terdiri dari:

1) Unsur Setiap Orang

2) Unsur Tanpa Hak atau Melawan Hukum

3) Unsur dengan permufakatan jahat menawarkan untuk dijual, menjual, membeli, menerima menjadi perantara dalam jual beli, menukar atau menyerahkan Narkotika Golongan I bukan tanaman yang beratnya lebih dari 5 (lima) gram: 
Dan dakwaan kedua Pasal 112 ayat (1) Jo132 ayat (1) UU No.35 Tahun 2009 tentangNarkotika, yang unsur-unsurnya terdiri dari:

1) Unsur Setiap Orang

2) Unsur dengan permufakatan jahat tanpa hak dan melawan hukum memiliki, menyimpan, menguasai, atau menyediakan Narkotika Golongan I bukan tanaman.

Dengan memperhatikan uraian unsur-unsur diatas, dengan demikian telah terbukti secara sah menurut hukum dan meyakinkan. Majelis hakim juga menjatuhkan pidana kepada terdakawa dengan pidana mati. Peneliti tidak sepakat dengan putusan hakim yang menjatuhkan hukuman mati kepada terdakwa, hakim tidak menyesuaikan hukumannya dengan perbuatannya yang hanya sebagai perantara saja tidak sebagai seorang bandar, walupun dalam dakwaan kedua terdakwa memiliki dan menyuruh orang lain mencari narkotika jenis shabu yang berat keseluruhannya 4 gram. Di samping itu juga terdakwa tidak pernah dihukum. Dengan menjatuhkan pidana mati kepada terdakwa tidak begitu berpengaruh untuk pemberantasan peredaran narkotika, karena pemilik/bandar narkotika tersebut belum ditangkap, dimana bandar tersebut dapat menyuruh orang lain lagi untuk melakukan penyaluran narkotika miliknya, mengingat orang-orang yang di gunakan bandar adalah orang yang berasal dari kalangan bawah seperti terdakwa yang hanya merupakan nelayan. Menimbang demi kemanusiaan seharusnya hakim memberi kesempatan kepada terdakwa untuk menyesali dan merubah dirinya agar tidak melakukan tindak pidana narkotika lagi maupun tindak pidana lainnya.

\section{D.Kesimpulan}

Berdasarkan uraian pendapat dan pembahasan terhadap putusan Nomor 1991/Pid.Sus/2019/PN Mdn, maka penulis memperoleh kesimpulan sebagai berikut:

a. Dasar pertimbangan hakim dalam penjatuhan pidana terhadap terdakwa sebagai pelaku perantara dalam jual beli narkotika di Pengadilan Negeri Medan pada putusan Nomor 1991/Pid.Sus/2019/PN Mdn, bahwasanya telah berdasarkan pertimbangan yuridis dan Non yuridis. Pertimbangan Hakim secara Yuridis yaitu alat bukti yang sah berupa:

Dakwaan Penuntut umum, keterangan saksi, Barang bukti, alat bukti surat, keterangan terdakwa yang terungkap dipersidangan.

Dasar pertimbangan non yuridis yaitu berdasarkan kebijaksanaan dan keyakinan hati nurani seorang hakim, dalam melihat keadaan yang digolongkan antara lain: Latar belakang perbuatan, Kondisi diri, Kondisi sosial ekonomi dan Sifat sopan dan santun terdakwa dalam persidangan.

Selain itu hal-hal yang meringankan dan memberatkan juga masuk kedalam dasar pertimbangan hakim yang bersifat non yuridis.

b. Penjatuhan pidana mati dilihat dari segi masyarakat sudah memenuhi rasa keadilan karena narkotika yang diterima dan disalurkan terdakwa total keseluruhannya adalah $70 \mathrm{~kg}$ jenis sabu-sabu dan 2.985 butir ekstasi dan berpotensi merusak generasi bangsa sehingga hakim menjatuhkan pidana mati kepada terdakwa, tetapi bagi terdakwa pidana mati belum memenuhi rasa keadilan. Terdakwa merupakan perantara jual beli narkotika serta peran terdakwa cukup ringan dibanding dengan bandar narkotika selain itu terdakwa belum pernah dihukum sebelumnya. 
Jurnal Magister Hukum Program Pascasarjana Universitas HKBP Nommensen

Volume 02 Nomor o1 Januari 2021 Halaman. 24-36 e-ISSN: 2723-164X p-ISSN: 2722-9858

http://ejournal.uhn.ac.id/index.php/opinion

\section{Daftar Pustaka}

Gultom, Maidin, Perlindungan Hukum Terhadap Anak dan Perempuan, Bandung: Refika Aditama, 2014

Gunadi, Ismu dan Efendi, Jonaedi, Cepat dan Mudah Memahami Hukum Pidana, Jakarta: Kencana, 2014

Huda, Chairul, Dari Tiada Pidana Tanpa Kesalahan Menuju Kepada Tiada Pertanggungjawaban Pidana Tanpa Kesalahan, Jakarta: Kencana, 2011

Harahap, Yahya, Pembahasan Permasalahan dan Penerapan KUHAP Pemeriksaan Sidang Pengadilan, Banding, Kasasi dan Peninjauan Kembali. Jakarta: Sinar Grafika, 2016

Harahap, Yahya, Pembahasan, Permasalahan Dan Penerapan KUHP Penyidikan dan Penuntutan, Jakarta: Sinar Grafika, 2017

Hiariej, O.S. Eddy, Prinsip-Prinsip Hukum Pidana, Yogyakarta: Cahaya Atma Pustaka, 2016

Muhammad, Rusli, Potret Lembaga Pengadilan Indonesia, Jakarta: RajaGrafindo Persada, 2016

Hamzah, Andi, Hukum Pidana Indonesia, Jakarta: Sinar Grafika, 2019

Lamintang, P.A.F, Hukum Penitensier Indonesia, Jakarta: Sinar Grafika, 2012

Mustofa, Wildan, Kode Etik Hakim, Jakarta: Kencana Prenada Group, 2013

Mulyadi, Lilik. Hukum Acara Pidana Normatif, Teoretis, Praktik, dan Permasalahannya, Bandung: Alumni, 2012

Marlina, Hukum Penitensier, Bandung: Refika Aditama, 2011

Manullang, Herlina, Pengantar Ilmu Hukum Indonesia, Medan: UHN Press, 2010

Makaro, Taufik, Tindak Pidana Narkotika, Jakarta: Ghalia Indonesia, 2018

Nainggolan, Ojak, Hukum Tindak Pidana Umum, Medan: UHN Press, 2010

Prasetyo, Teguh. Hukum Pidana. Jakarta: Raja Grafindo Persada, 2018

Rahim, Abdur dan Hafiz, Muhammad, Hukuman Mati Problem Legalitas dan Kemanusiaan, Jakarta: INTRANS Institute, 2015

Renggong, Ruslan, Hukum Pidana Khusus, (Jakarta: Prenadmedia Group, 2016)

Syamsu, Ainul, Muhammad, Pergeseran Turut Serta Melakukan dalam Ajaran Penyertaan, Jakarta: Prenadamedia Group, 2014

Yanto, Oksidelfa, Negara Hukum Kepastian, Keadilan dan Kemanfaatan Hukum Dalam Sistem Peradilan Indonesia. Bandung: Pustaka Reka Cipta, 2020

Peraturan Perundang-undangan

Kitab Undang-Undang Hukum Pidana (KUHP)

Kitab Undang-Undang Hukum Acara Pidana (KUHAP)

Undang-Undang Nomor 35 Tahun 2009 tentang NarkotikaUndang-Undang Nomor 48 Tahun 2009 tentang Kekuasaan Kehakiman

\section{Internet}

https://ppid.bnn.go.id/wp-content/Uploads/Sites/2/2020/o7/7..Survei-Prevalensi-Penyalah gunaan-Narkoba-Kuantitatif-2019.pdf, hal. 5 (diakses 14 juli 2020)

https://bnn.go.id/konten/unggahan/2019/12/DRAFT-LAMPIRAN-PRESS-RELEASE\%2oakhir\%20TAHUN-2019-1-.pdf

https://nasional.kompas.com/read/2019/o6/26/11421691/bnn-sebut-penyalahgunaan-dan peredaran-narkotika-semakin-meningkat, (diakses 14 juli 2020) 
Nommensen Journal of Legal Opinion (NJLO)

Jurnal Magister Hukum Program Pascasarjana Universitas HKBP Nommensen

Volume 02 Nomor o1 Januari 2021 Halaman. 24-36 e-ISSN: 2723-164X p-ISSN: 2722-9858

http://ejournal.uhn.ac.id/index.php/opinion

http://asakeadilan.blogspot.com/2015/o1/sekilastindakpidananarkotika_5.htmlxt 